is nevertheless prepared to assist in measures for defence against anti-democratic movements. To this end, it stresses the importance of the immediate formation of an organization to see that the most efficient use is made of scientific knowledge; the following points are put forward for consideration :

"(1) It is in the best interests of the country that scientists should be utilized in seientific work, and that the organization and control of scientific work should be in the hands of scientists.

"(2) The professional organization of scientists should play an important part in drawing up and operating any scheme of organization and also be represented on scientific advisory committees to the defence departments.

“(3) In any scheme of registration, scientists should be grouped on a laboratory basis, no matter whether university, special research or industrial. It is particularly important that scientific workers in industry should be included in any such scheme and not left at the disposal of individual employers. Further, scientists should be consulted now with regard to such organization, firstly on the grounds of efficiency and secondly to secure its democratic working.

“(4) Some machinery should be provided whereby scientists, including those in service departments, may exercise a right of criticism on purely scientific and technical matters.

"(5) It is important that scientific and technical as well as medical education should be maintained in time of war."

\section{New Chancellor at the University of Leeds}

ON January 17, with appropriate ceremony, the University of Leeds installed the Duke of Devonshire as chancellor in succession to his father, who had occupied that post for nearly thirty years, having succeeded the first chancellor of the University, the Marquess of Ripon, in 1909. The proceedings commenced with a lunch to the honorary graduands and to the representatives of other universities and of local education authorities, given by the Court of the University, in the fine new Civic Hall rendered available through the courtesy of the Lord Mayor of Leeds. The ceremony of installation took place in the Town Hall, in the presence of representatives of all sections of the University, and other universities, of local authorities in Yorkshire, together with other dignitaries. His Grace was received by the vicechancellor, Mr. B. Mouat Jones, who presented him with the scroll recording his admission to the honorary degree of doctor of laws of the University, and then installed him as chancellor, delivering a brief address of welcome. After the chancellor's response, a number of honorary degrees were conferred. Earl Baldwin of Bewdley and the Right Hon. W. S. Morison, Minister of Agriculture and Fisheries, were presented for the degree of LL.D. The degree of D.Sc. was conferred upon Sir Arthur Eddington, Plumian professor of astronomy and director of the Observatory, Cambridge, upon Sir John Ledingham, director of the Lister Institute, and upon Dr. J. S. B. Stopford, formerly professor of anatomy and now vice-chancellor of the University of Manchester. In the evening, the Chancellor and the Duchess of Devonshire received the guests at a reception in the University, when many scientific and technological departments were thrown open, special demonstrations being on view. These exhibits remained open for inspection by the general public throughout the following day.

\section{Botanic Gardens of the World}

WE have received the second edition of the list of botanic gardens of the world compiled under the direction of Dr. Stuart Gager, director of the Brooklyn Botanic Garden ("Botanic Gardens of the World : Materials for a History". Brooklyn Bot. Rec., 27, No. 3, July 1938. Price 2 dollars 50 cents). Apart from its intrinsic value to botanists, the list will prove helpful to research botanists and teachers of botany who may require information or material from definite localities. In this way, the list forms a sure guide. But there are inconsistencies in the information given concerning each individual garden. This is due to the fact that the compiler has been at great pains to make the information authoritative by obtaining it from the source, namely, the gardens themselves. In this, Dr. Gager experienced certain difficulties, since, though most garden officials supplied all the necessary information, some made no or scant reply to the questionnaires sent. Where the information can be considered complete, it is of great utility. For example, under the Royal Botanic Gardens, Kew, are listed date of establishment, area, list of directors, organization, source of income, library, herbarium, arboretum and fruticetum, plantations, publications, museums, etc. The list is not intended to be simply a guide to existing botanic gardens, but as material for a history of botanic gardens, existing or defunct, and "thus as a contribution to one of the most important phases of the history of the organization and administration of botanical science, from the time of Aristotle to the present". Such a history would receive a warm welcome from all botanists, since we believe no such comprehensive history exists at present. We would suggest one slight improvement in the next edition of this list, which would undoubtedly render reference more easy. The gardens are arranged alphabetically under each country, and the latter in turn are arranged alphabetically. There are, however, no page headings (except page number). It would be a distinct advantage if the name of the country were placed at the top of each page.

\section{Folk-lore and Medicine}

At a meeting of the West London Medico-Chirurgical Society on January 13, Dr. J. D. Rolleston read a paper on "Folk-lore and Medicine". He said that since the publication in 1927 of the late Dr. Dan McKenzie's work entitled "The Infancy of Medicine : an Enquiry into the influence of Folk-lore upon the Evolution of Scientific Medicine", the subject of folklore in connexion with medicine has attracted little attention in Great Britain, in marked contrast with the enthusiasm which it has provoked on the Continent. The various prophylactic and therapeutic measures in folk-lore medicine, in which the curative methods far outnumber the preventive, can be ranged under one or more of the following headings: (1) trans- 